\title{
PENGARUH PENERAPAN MODEL PEMBELAJARAN PROJECT BASED LEARNING (PBL) MELALUI PENGGUNAAN MEDIA UNIT KEGIATAN BELAJAR MANDIRI (UKBM) TERHADAP HASIL BELAJAR SISWA
}

\author{
Gita Maelani', Rini Agustin Eka Yanti², Uu Adkur Sutendy ${ }^{3}$ \\ 1,2,3Program Studi Pendidikan Akuntansi Universitas Galuh, J.L. R. E. Martadinata No.150, Ciamis, Indonesia \\ E-mail: maelanigita101@gmail.com
}

\begin{abstract}
The low of student learning outcomes has become a problem at school. The purpose of this study is to determine: (1) Differences in student learning outcomes using Project Based Learning (PBL) models at initial and final measurements; (2) Differences in student learning outcomes using conventional learning models at initial and final measurements; (3) Differences in learning outcomes between students who use the Project Based Learning (PBL) model and those who use conventional learning models through the use of the media Independent Learning Activities Unit (UKBM) in the final measurements of class X MIPA SMA Negeri 1 Ciamis. This research method is an experimental research using quasi experimental with the design of Nonequivalent Control Group Design. Data analysis techniques on student learning outcomes is by using the t-test. The results showes that: (1) There are positive and significant differences on student learning outcomes with the high N-Gain category on the use of Project Based Learning (PBL) learning models at the initial and final measurements in the experimental group of class X MIPA 1 SMA Negeri 1 Ciamis; (2) There are positive and significant differences in student learning outcomes with the $N$-Gain category of Medium on the use of conventional learning models in the initial measurements and final measurements in the control group of class X MIPA 2 SMA Negeri 1 Ciamis; (3) There are positive and significant differences in student learning outcomes on the use of Project Based Learning (PBL) learning models that are superior compared to student learning outcomes that use conventional methods in the final measurement through the use of the Media Independent Learning Activity Unit (UKBM) in class X MIPA of SMA Negeri 1 Ciamis.
\end{abstract}

Keywords: Project Based Learning (PBL), Learning Outcomes

\begin{abstract}
ABSTRAK
Permasalahan di sekolah menunjukkan masih rendahnya hasil belajar siswa. Tujuan dari penelitian ini adalah untuk mengetahui: (1) Perbedaan hasil belajar siswa yang menggunakan model pembelajaran Project Based Learning (PBL) pada pengukuran awal dan pengukuran akhir, (2) Perbedaan hasil belajar siswa yang menggunakan model pembelajaran konvensional pada pengukuran awal dan pengukuran akhir, (3) Perbedaan hasil belajar siswa yang menggunakan model pembelajaran Project Based Learning (PBL)dibandingkan dengan hasil belajar siswa yang menggunakan model pembelajaran konvensionalmelalui penggunaan media Unit Kegiatan Belajar Mandiri (UKBM) pada pengukuran akhir di kelas X MIPA SMA Negeri 1 Ciamis. Metode penelitian ini merupakan penelitian eksperimen dengan rancangan desain quasi eksperimen Nonequivalent Control Group Design. Teknik analisis data hasil belajar siswa yaitu dengan menggunakan uji t. Hasil penelitian menunjukan bahwa: (1) Terdapat perbedaan hasil belajar siswa yang positif dan signifikan dengan kategoriN-Gain tinggi pada penggunaan model pembelajaran Project Based Learning (PBL) pada pengukuran awal dan pengukuran akhir pada kelas eksperimen di kelas X MIPA 1 SMA Negeri 1 Ciamis. (2) Terdapat perbedaan hasil belajar siswa yang yang positif dan signifikan dengan kategori N-Gain sedang pada penggunaan model pembelajaran konvensional pada pengukuran awal dan pengukuran akhir pada kelas kontrol di kelas X MIPA 2 SMA Negeri 1 Ciamis. (3) Terdapat perbedaan hasil belajar siswa yang positif dan signifikan pada penggunaan model pembelajaran Project Based Learning (PBL) lebih unggul dibandingkan dengan hasil belajar siswa yang menggunakan metode konvensional pada pengukuran akhir melalui penggunaan Media Unit Kegiatan Belajar Mandiri (UKBM) di kelas X MIPA SMA Negeri 1 Ciamis
\end{abstract}

Kata Kunci: Model Pembelajaran Project Based Learning (PBL), Hasil Belajar.

Cara sitasi: Maelani, G., Yanti, R. A. E \& Sutendy, U. A. 2021. Pengaruh penerapan model pembelajaran project based learning $(\mathrm{pbl})$ melalui penggunaan media unit kegiatan belajar mandiri (ukbm) terhadap hasil belajar siswa. $J$ KIP (Jurnal Keguruan dan IImu Pendidikan), 2 (2), 71-80. 


\section{PENDAHULUAN}

Perubahan zaman menuntut setiap manusia untuk mengikuti segala perubahan yang terjadi, jika perubahan yang dimaksud adalah dalam hal yang positif. Tuntutan itu harus cepat direspon agar setiap orang memiliki kecakapan atau potensi diri yang dapat memenuhi kebutuhan hidup di zaman yang telah berubah, sehingga mendapatkan kesempatan yang sama dengan orang lainnya. Upaya untuk mengembangkan potensi diri dan meningkatkan kualitas manusia sangat diperlukan, terutama dalam hal pengetahuan, sikap, dan keterampilan. Keseluruhan aspek kualitas tersebut saling berkaitan sehingga tidak dapat dipisahkan antara satu dengan yang lainnya. Upaya untuk mengembangkan potensi tersebut bisa didapatkan melalui proses pembelajaran.

Dalam hal ini, Sudjana (2017) berpendapat bahwa: "Proses adalah kegiatan yang dilakukan oleh siswa dalam mencapai tujuan pengajaran, sedangkan hasil belajar adalah kemampuankemampuan yang dimiliki siswa setelah ia menerima pengalaman belajarnya". Berdasarkan pendapat tersebut nampak bahwa hasil belajar adalah kemampuan dan keterampilan yang dimiliki oleh peserta didik setelah peserta didik menerima pengalaman pembelajaran. Kemampuan dan keterampilan tersebut mencakup ranah afektif, kognitif dan psikomotor. Hasil belajar peserta didik cenderung bersifat variatif, sesuai dengan kemampuan dan komponen-komponen pendukung dalam proses pembelajaran.

KKM meningkat pada setiap mata pelajaran seiring dengan tuntutan zaman dan berkembangnya kurikulum. Permasalahan saat ini adalah masih banyak peserta didik yang kesulitan dalam mencapai KKM. Fenomena di sekolah menunjukkan adanya masalah hasil belajar peserta didik. Setiap sekolah tentu menghadapi permasalahan yang sama mengenai KKM yang berhubungan dengan hasil belajar peserta didik mengingat pada kemampuan peserta didik yang berbeda-beda.

Berdasarkan pengamatan awal di SMA Negeri 1 Ciamis ternyata masih terdapat beberapa hasil belajar peserta didik yang masih belum mencapai KKM. Hal ini dapat dilihat dari nilai ulangan harian peserta didik khususnya mata pelajaran Ekonomi Lintas Minat Kelas X MIPA Semester I di SMA Negeri 1 Ciamis tahun ajaran 2018/2019 dengan KKM sebesar 75. Berikut daftar nilai yang disajikan dalam bentuk tabel di bawah ini:

Table 1. Nilai Mata Pelajaran Lintas Minat Ekonomi

\begin{tabular}{cccccccc}
\hline \multirow{2}{*}{ Kelas } & \multirow{2}{*}{$\begin{array}{c}\text { Jumlah } \\
\text { Siswa }\end{array}$} & KKM & Nilai Rata-rata & \multicolumn{2}{c}{ Peserta Didik yang } & \multicolumn{2}{c}{ Peserta Didik yang Belum } \\
& & & & Jumlah & $\%$ & Mencapai KKM \\
X MIPA 1 & 36 & 75 & 71,44 & 19 & 52,8 & 17 & 47,2 \\
X MIPA 2 & 36 & 75 & 63,64 & 20 & 55,5 & 16 & 44,5 \\
X MIPA 3 & 36 & 75 & 63,33 & 7 & 19,4 & 29 & 80,6 \\
X MIPA 4 & 36 & 75 & 71,95 & 15 & 41,7 & 21 & 58,3 \\
Total & 144 & - & 67,59 & 61 & 42,4 & 83 & 57,6 \\
\hline
\end{tabular}

Berdasarkan Tabel 1 tersebut di atas, dapat nampak bahwa ketuntasan belajar peserta didik cukup rendah. Persentase ketidaktuntasan peserta didik sebesar $57,64 \%$, artinya kurang dari $50 \%$ rata-rata persentase peserta didik mencapai KKM. Hal ini perlu ditindaklanjuti karena rendahnya nilai pengetahuan peserta didik mempresentasikan bahwa peserta didik kurang memahami konsep materi pembelajaran. Oleh sebab itu, apabila peserta didik mendapatkan hasil belajar yang rendah secara terus menerus dikhawatirkan dapat menghambat proses pembelajaran dan peserta didik akan mengalami kesulitan dalam memahami materi berikutnya. Untuk meningkatkan efisiensi dan efektivitas ketercapaian kompetensi lulusan, maka pembelajaran selalu mengalami perubahan, perkembangan dan perbaikan sesuai dengan perkembangan di segala bidang kehidupan. Hal ini menyebabkan perlu adanya sebuah inovasi pembelajaran di sekolah. 
Pembelajaran merupakan suatu sistem yang terdiri dari berbagai komponen yang saling berhubungan. Komponen tersebut meliputi: tujuan, materi, metode dan evaluasi. Keempat komponen pembelajaran tersebut harus diperhatikan oleh guru dalam memilih dan menentukan media, model strategi dan pendekatan apa yang akan digunakan dalam kegiatan pembelajaran. Setelah merumuskantujuan dan komponen pembelajaran yang digunakan maka mengakibatkan munculnya kebutuhan peserta didik untuk mencapai tujuan pembelajaran tersebut. Model pembelajaran merupakan salah satu komponenyang dapat mempengaruhi proses pembelajaran, maka guru hendaknya menyesuaikan kondisi peserta didik dengan kebutuhannya dan mampu mengubah pembelajaran menjadi terpusat pada peserta didik (student centered learning) serta merangsang peserta didik untuk ikut aktif dalam proses belajar dengan penyajian media pembelajaran yang lebih menarik, sehingga kesulitan proses pembelajaran dapat di atasi dengan baik dan mampu meningkatkan kemampuan dan partisipasi aktif peserta didik.

Berdasarkan permasalahan tersebut di atas, Untuk meningkatkan hasil belajar peserta didik tersebut maka model pembelajaran Project Based Learning (PBL) mungkin dapat dijadikan sebagai salah satu alternatif model pembelajaran. Made Wena (dalam Al-Tabany, 2015) mendefinisikan bahwa "project based learning/pembelajaran berbasis proyek sebagai model pembelajaran yang memberikan kesempatan kepada guru untuk mengelola pembelajaran di kelas dengan melibatkan kerja proyek." Dengan model pembelajaran ini peserta didik melakukan eksplorasi, penilaian, interpretasi dan analisis dari berbagai media untuk menghasilkan berbagai produk dari pengalaman pembelajaran. Dalam model pembelajaran ini guru bertindak sebagai motivator dan fasilitator, dimana peserta didik diberi peluang bekerja secara konstruktif untuk melakukan suatu investigasi yang mendalam terhadap suatu topik pembelajaran.

Pembelajaran berbasis proyek merupakan pembelajaran yang didukung oleh atau berpijak pada teori belajar konstruktivistik. Menurut Jollife (dalam Rusman, 2017) teori belajar kontruktivisme adalah sebagai berikut:

Teori belajar kontruktivisme dipelopori oleh Piaget, Bruner, dan Vygotsky pada awal abad 20an yang mempunyai pandangan bahwa pengetahuan dan pemahaman tidaklah diperoleh secara pasif akan tetapi dengan cara yang aktif melalui pengalaman personal dan aktivitas eksperiental, konsep utama dari kontruktivisme adalah bahwa peserta didik adalah aktif dan mencari untuk membuat pengertian tentang apa yang ia pahami, ini berarti belajar membutuhkan untuk focus pada scenario berbasis masalah, belajar berbasis proyek, belajar berbasis tim, simulasi, dan penggunaan teknologi.

Kemudian dalam hal ini Priansa, (2015) mengemukakan bahwa "Pembelajaran berbasis proyek memberikan hasil belajar berupa pengetahuan (knowledge), keterampilan (skill atau psikomotor), dan sikap (attitude atau afektif), maka evaluasi yang dapat digunakan oleh guru terhadap peserta didik adalah dengan menggunakan evaluasi yang mampu mengukur ketiga ranah tersebut."Model pembelajaran berbasis proyek memberikan peluang kepada peserta didik secara bebas melakukan kegiatan percobaan, mengkaji literatur di perpustakaan, melakukan browsing di internet dan berkolaborasi dengan guru. Oleh karena itu sumber belajar menjadi lebih terbuka dan bervariasi, termasuk dalam mengeksplorasi lingkungan.

Selain model pembelajaran, komponen lain yang harus diperhatikan adalah media pembelajaran, dengan model dan media pembelajaran yang tepat maka tujuan pembelajaran dapat tercapai secara optimal.Menurut Gagne dan Briggs (dalam Arsyad, 2016) secara implisit mengemukakan bahwa "Media pembelajaran meliputi alat yang secara fisik digunakan untuk menyampaikan isi materi pengajaran, yang terdiri dari antara lain buku, tape recorder, kaset, video camera,video recorder, film, slide (gambar bingkai), foto, gambar, grafik, televisi, dan komputer".Pada tahun 2014, pemerintah telah menetapkan suatu program baru dalam pendidikan berupa Unit Kegiatan Belajar Mandiri (UKBM). Direktorat Pembinaan SMA Kementerian Pendidikan dan Kebudayaan, (2017) menyiratkan bahwa: "UKBM itu sendiri merupakan satuan pelajaran kecil 
yang disusun secara berurutan dari mudah sampai ke yang sukar." UKBM merupakan satuan pelajaran kecil yang disusun secara berurutan dari mudah sampai ke yang sukar sebagai perangkat belajar bagi peserta didik untuk mencapai kompetensi pengetahuan dan keterampilan pada pembelajaran dengan menggunakan sistem kredit semester (SKS). Dari beberapa sekolah yang berada di Jawa Barat yang menerapkan SKS dengan menggunakan UKBM salah satunya yaitu SMA Negeri 1 Ciamis.

Penelitian mengenai model pembelajaran Project Based Learning (PBL) pernah dilakukan oleh Madiastuty (2019), hasil akhir penelitian yang di dapatkan menunjukan bahwa terdapat pengaruh penerapan model pembelajaran Project Based Learning (PjBL) melalui penggunaan Unit Kegiatan Belajar Mandiri (UKBM) terhadap hasil belajar kimia siswa di MAN 3 Pekanbaru, dan untuk koefisien pengaruh yaitu sebesar $12 \%$.

Kemudian terdapat penelitian lain yang membahas mengenai model pembelajaran Project Based Learning (PBL) yang dilakukan oleh Purwanti (2018). Hasil penelitian menunjukkan bahwa terdapat pengaruh model Project Based Learning terhadap hasil belajar ekonomi. Kesimpulan hasil belajar siswa yang menggunakan model pembelajaran Project based learning lebih tinggi dari pada hasil belajar siswa yang menggunakan model Direct Instruction pada siswa SMA Negeri 6 Kota Jambi. Berdasarkan kesimpulan tersebut maka, sebaiknya dalam melakukan pengajaran menggunakan model pembelajaran project based learning khususnya untuk meningkatkan kemampuan kognitif siswa.

\section{METODE PENELITIAN}

Metode penelitian yang digunakan dalam penelitian ini yaitu metode penelitian eksperimen.Adapun desain eksperimenyang digunakan yaitu quasi eksperimental design, rancangandesain quasi eksperimen yang akan digunakan dalam penelitian adalah Nonequivalent Control Group Design. Menurut Sugiyono, (2015) "Desain ini sama dengan pretest-posttest control group design, hanya pada desain ini kelompok eksperimen maupun kelompok kontrol tidak dipilih secara random". Berikut rancangan penelitian yang akan digunakan:

\section{Tabel 2. Desain penelitian}

\begin{tabular}{lccc}
\hline Kelas & Tes Awal & Perlakuan & Tes akhir \\
\hline Eksperimen & $O_{1}$ & $\mathrm{X}$ & $O_{2}$ \\
Kontrol & $O_{3}$ & & $O_{4}$ \\
\hline
\end{tabular}

Sumber: Sugiyono (2016)

Keterangan:

$O_{1}=$ Tes awal kelas eksperimen untuk mengetahui pengetahuan awal peserta didik

$O_{3}=$ Tes awal kelas kontrol untuk mengetahui pengetahuan awal peserta didik

$\mathrm{X}=$ Perlakuan diberikan kepada kelas eksperimen, yaitu penerapan Model Pembelajaran Active Knowledge Sharing.

$\mathrm{O}_{2}=$ Tes akhir kelas eksperimen setelah mengikuti pembelajaran dengan melakukan penerapan Model Pembelajaran Active Knowledge Sharing

$\mathrm{O}_{4}=$ Tes akhir kelas kontrol setelah mengikuti pembelajaran menggunakan model pembelajaran konvensional.

Adapun populasi dalam penelitian ini adalah seluruh siswa kelas X MIPA yang mengambil lintas minat mata pelajaran Ekonomi di SMA N 1 Ciamis yang berjumlah 144 siswa. Sedangkan sampel yang digunakan dalam penelitian ini yaitu sebanyak dua kelas sebagai kelas eksperimen dan kelas kontrol. Teknik pengambilan objek dilakukan dengan purposive sample atau sampel bertujuan. Menurut Arikunto (2013) "Sampel bertujuan dilakukan dengan cara mengambil subjek bukan didasarkan atas strata, random atau 
daerah tetapi didasarkan atas adanya tujuan tertentu". Berdasarkan rekomendasi dari guru mata pelajaran Ekonomi kelas $X$ di SMA Negeri 1 Ciamis dipilih dua kelas yang memiliki karakteristik sama yaitu kelas $X$ MIPA 1 sebagai kelas eksperimen dan X MIPA 2 sebagai kelas kontrol.Teknik analisis yang digunakan dapat dilakukan dengan menggunakan langkah-langkah diantaranya, Uji instrumen penelitian, prasyarat uji Statistik dan uji hipotesis dengan menggunaka uji t.

\section{HASIL DAN PEMBAHASAN}

Adapun data rekapitulasi hasil belajar peserta didik berdasarkan pengukuran awal (pretest) dan pengukuran akhir (posttest) pada kelas eksperimen dengan perlakuan model pembelajaran Project Based Learning (PBL) adalah sebagai berikut.

Tabel 3. Data Hasil Kelas Eksperimen

\begin{tabular}{cccc}
\hline No. & Keterangan & Pretest & Posttest \\
\hline 1 & Nilai Terendah & 40 & 74 \\
2 & Nilai Tertinggi & 86,7 & 100 \\
3 & Jumlah peserta didik & 34 & 34 \\
4 & Rata-rata & 64,12 & 89,62 \\
\hline
\end{tabular}

Berdasarkan tabel 3 tersebut di atas, dapat nampak bahwa hasil belajar peserta didik kelas eksperimen dengan jumlah peserta didik 34 orang pada saat dilakukan pengukuran awal (pretest) diperoleh nilai terendah 40 dan nilai tertinggi 86,7 dengan rata-rata nilai 64,12. Kemudian pada pengukuran akhir (posttest) setelah mendapatkan perlakuan model pembelajaran Project Based Learning (PBL) dengan jumlah siswa yang mengikuti posttest sebanyak 34 orang diperoleh nilai terendah 74 dan nilai tertinggi 100 dengan rata-rata nilai 89,62. Ini menunjukan bahwa terjadi peningkatan hasil belajar peserta didik dengan penerapan model pembelajaran Project Based Learning (PBL) melalui media Unit Kegiatan Belajar Mandiri (UKBM) pada pengukuran awal (pretest) dan pengukuran akhir (posttest) pada kelas eksperimen di kelas X MIPA 1 SMA Negeri 1 Ciamis.

Adapun data hasil belajar peserta didik kelas kontrol (X MIPA 2) pada pengukuran awal (pretest) dan pengukuran akhir (posttest) adalah sebagai berikut:

Tabel 4. Data Hasil Kelas Kontrol

\begin{tabular}{cccc}
\hline No. & Keterangan & Pretest & Posttest \\
\hline 1 & Nilai Terendah & 26,7 & 60 \\
2 & Nilai Tertinggi & 80 & 93 \\
3 & Jumlah peserta didik & 33 & 33 \\
4 & Rata-rata & 59,6 & 78,97 \\
\hline
\end{tabular}

Berdasarkan tabel 4 tersebut di atas, dapat nampak bahwa hasil belajar peserta didik kelas kontrol dengan jumlah peserta didik 33 orang pada saat dilakukan pengukuran awal (pretest) diperoleh nilai terendah 26,7 dan nilai tertinggi 80 dengan rata-rata nilai 59,60. Kemudian pada pengukuran akhir (posttest) setelah mendapatkan perlakuan model pembelajaran konvensionaldengan jumlah siswa yang mengikuti posttest sebanyak 33 orang diperoleh nilai terendah 60 dan nilai tertinggi 93 dengan rata-rata nilai 78,97. Ini menunjukan bahwa terjadi peningkatan hasil belajar peserta didik dengan penerapan model pembelajaran konvensional melalui media Unit Kegiatan Belajar Mandiri (UKBM) pada pengukuran awal (pretest) dan pengukuran akhir (posttest) pada kelas kontrol di kelas X MIPA 2 SMA Negeri 1 Ciamis.

Adapun data hasil belajar peserta didik kelas eksperimen (X MIPA 1) dan kelas kontrol (X MIPA 2) pada pengukuran akhir (posttest) adalah sebagai berikut: 
Tabel 5. Data Hasil Posttest Kelas Eksperimen dan Kontrol

\begin{tabular}{cccc}
\hline No. & Keterangan & Kelas Eksperimen & Kelas Kontrol \\
\hline 1 & Nilai Terendah & 74 & 60 \\
2 & Nilai Tertinggi & 100 & 93 \\
3 & Jumlah peserta didik & 34 & 33 \\
4 & Rata-rata & 89,62 & 78,97 \\
\hline
\end{tabular}

Berdasarkan tabel 5 tersebut di atas, dapat nampak bahwa hasil belajar peserta didik kelas eksperimen dengan jumlah peserta didik 34 orang pada saat dilakukan pengukuran akhir (postest) diperoleh nilai terendah 74 dan nilai tertinggi 100 dengan rata-rata nilai 89,62. Sedangkan hasil belajar peserta didik kelas kontrol dengan jumlah peserta didik 33 orang pada saat dilakukan pengukuran akhir (postest) diperoleh nilai terendah 60 dan nilai tertinggi 93 dengan rata-rata nilai 78,97. Ini menunjukan bahwa terjadi perbedaan hasil belajar peserta didik dengan penerapan model pembelajaran Project Based Learning (PBL) dibandingkan hasil belajar peserta didik dengan penggunaan model pembelajaran konvensional melalui media Unit Kegiatan Belajar Mandiri (UKBM) pengukuran akhir (posttest) pada kelas eksperimen di X MIPA 1 dan pada kelas kontrol di X MIPA 2 SMA Negeri 1 Ciamis.

Berdasarkan perhitungananalisis hasil belajar siswa menggunakan uji $t$ yang telah dilakukan, maka didapatkan hasil rekapitulasi dari ketiga pengujian hipotesis sebagai berikut:

Table 6. Rekapitulasi Hasil Penelitian

\begin{tabular}{|c|c|c|c|c|c|c|c|c|}
\hline Hipotesis & Kelas & $\bar{X}$ & $\boldsymbol{S}$ & $d k$ & thitung & $\propto$ & $t_{\text {tabel }}$ & simpulan \\
\hline 1) & $\begin{array}{l}\text { Eksperimen } \\
\text { Kontrol }\end{array}$ & $\begin{array}{l}64,12 \\
89,62\end{array}$ & $\begin{array}{c}12,17 \\
6,01\end{array}$ & 66 & 11,0869 & 0,05 & 1,6686 & $\begin{array}{c}\mathrm{H}_{\mathrm{a}} \text { diterima } \\
\mathrm{H}_{0} \text { ditolak }\end{array}$ \\
\hline 2) & $\begin{array}{l}\text { Eksperimen } \\
\text { Kontrol }\end{array}$ & $\begin{array}{l}59,60 \\
78,97\end{array}$ & $\begin{array}{c}12,46 \\
9,42\end{array}$ & 64 & 7,8104 & 0,05 & 1,6683 & $\begin{array}{c}\mathrm{H}_{\mathrm{a}} \text { diterima } \\
\mathrm{H}_{0} \text { ditolak }\end{array}$ \\
\hline 3) & $\begin{array}{l}\text { Eksperimen } \\
\text { Kontrol }\end{array}$ & $\begin{array}{l}89,62 \\
78,97 \\
\end{array}$ & $\begin{array}{l}5,92 \\
9,28 \\
\end{array}$ & 65 & 6,6563 & 0,05 & 1,66864 & $\begin{array}{c}\mathrm{H}_{\mathrm{a}} \text { diterima } \\
\mathrm{H}_{0} \text { ditolak }\end{array}$ \\
\hline
\end{tabular}

Perbedaan Hasil Belajar Siswa yang Menggunakan Model Pembelajaran Project Based Learning (PBL) melalui Penggunaan Media Unit Kegiatan Belajar Mandiri (UKBM) pada Pengukuran Awal (Pretest) dan Pengukuran Akhir (Posttest) di Kelas X MIPA SMA Negeri 1 Ciamis

Berdasarkan hasil pengujian pada mata pelajaran lintas minat Ekonomi di kelas eksperimen $X$ MIPA 1 SMA Negeri 1 Ciamis dengan menggunakan rumus ujit, diketahui bahwa hasil belajar peserta didik dengan penerapan model pembelajaran Project Based Learning (PBL) melalui penggunaan media Unit Kegiatan Belajar Mandiri (UKBM) pada pengukuran awal (pretest) memiliki rata-rata nilai lebih kecil dari pengukuran akhir (posttest). Hal ini dibuktikan dengan nilai thitung sebesar 11,0869dan nilai $t_{\text {tabel }}$ sebesar 1,6686. Dengan demikian maka $t_{\text {hitung }} \geq t_{\text {tabel }}$ atau 11,0869> 1,6686 ini menunjukan bahwa terdapat perbedaan hasil belajar peserta didik yang signifikan pada penggunaan model pembelajaran Project Based Learning (PBL) melalui penggunaan media Unit Kegiatan Belajar Mandiri (UKBM) pada pengukuran awal (pretest) dan pengukuran akhir (posttest).

Perbedaan hasil belajar peserta didik juga dibuktikan dengan adanya peningkatan hasil belajar peserta didik pada pengukuran awal (pretest) dan pengukuran akhir (posttest) dengan menggunakan model pembelajaran Project Based Learning (PBL) memiliki nilai N-Gain rata-rata 0,70 , ini menunjukan bahwa peningkatan hasil belajar peserta didik pada kelas eksperimen di $X$ MIPA 1 SMA Negeri 1 Ciamis termasuk dalam kategori tinggi atau berada pada interval $G>70$ dengan persentasi peningkatan hasil belajar sebesar $40 \%$.

Hasil penelitian tersebut di atas, sejalan dengan pendapat Priansa (2015:182) bahwa "Pembelajaran berbasis proyek memberikan hasil belajar berupa pengetahuan (knowledge), keterampilan (skill atau psikomotor), dan sikap (attitude atau afektif), maka evaluasi yang dapat 
digunakan oleh guru terhadap peserta didik adalah dengan menggunakan evaluasi yang mampu mengukur ketiga ranah tersebut." Berdasarkan teori tersebut dapat nampak bahwa dengan penerapan model pembelajaran Project Based Learning (PBL)merupakan pembelajaran inovatif yang berpusat pada peserta didik (student centered). Dengan model ini peserta didik melakukan eksplorasi, penilaian, interpretasi dan analisis dari berbagai media untuk menghasilkan berbagai produk dari pengalaman pembelajaran. Dalam model pembelajaran ini guru bertindak sebagai motivator dan fasilitator, dimana peserta didik diberi peluang bekerja secara konstruktif untuk melakukan suatu investigasi yang mendalam terhadap suatu topik pembelajaran.

\section{Perbedaan Hasil Belajar Siswa yang Menggunakan Model Pembelajaran Konvensional Melalui Penggunaan Media Unit Kegiatan Belajar Mandiri (UKBM) pada Pengukuran Awal (Pretest) dan Pengukuran Akhir (Posttest) di Kelas X MIPA SMA Negeri 1 Ciamis}

Berdasarkan hasil pengujian pada mata pelajaran lintas minat Ekonomi di kelas kontrol $X$ MIPA 2 SMA Negeri 1 Ciamis dengan menggunakan rumus uji $t$, diketahui bahwa hasil belajar peserta didik dengan penerapan model pembelajaran konvensional melalui penggunaan media Unit Kegiatan Belajar Mandiri (UKBM) pada pengukuran awal (pretest) memiliki rata-rata nilai lebih kecil dari pengukuran akhir (posttest). Hal ini dibuktikan dengan nilai thitung sebesar7,8104dan nilai tabel sebesar 1,6690. Dengan demikian maka thitung $\geq t_{\text {tabel }}$ atau 7,8104 >1,6690 ini menunjukan bahwa terdapat perbedaan tingkat hasil belajar peserta didik yang signifikan pada penggunaan model pembelajaran konvensional melalui penggunaan media Unit Kegiatan Belajar Mandiri (UKBM) pada pengukuran awal (pretest) dan pengukuran akhir (posttest).

Perbedaan hasil belajar peserta didik juga dibuktikan dengan adanya peningkatan hasil belajar peserta didik pada pengukuran awal (pretest) dan pengukuran akhir (posttest) dengan menggunakan model pembelajaran konvensional memiliki nilai $\mathrm{N}$-Gain rata-rata 0,45 , ini menunjukan bahwa peningkatan hasil belajar peserta didik pada kelas kontrol di X MIPA 2 SMA Negeri 1 Ciamis termasuk dalam kategori sedang atau berada pada interval $0,30<G \leq 0,70$ dengan persentasi peningkatan hasil belajar sebesar $33 \%$.

Hasil penelitian tersebut di atas, dengan penggunaan model pembelajaran konvensional masih kurang tepat dibandingkan dengan menggunakan Model Pembelajaran Project Based Learning (PBL), guru harus lebih kreatif alam memilih model/metode pembelajaran karena peran guru sangat penting dalam meningkatkan hasil belajar peserta didik. Berdasarkan pendapat Slameto (2013:54) faktor - faktor yang mempengaruhi belajar adalah:

1) Faktor intern meliputi: a) Faktor jasmaniah terdiri dari faktor kesehatan dan faktor cacat tubuh; b) Faktor psikologis terdiri dari intelegensi, perhatian, minat, bakat, motif, kematangan, dan kesiapan; c) Faktor kelelahan baik kelelahan secara jasmani maupun kelelahan secara rohani.

2) Faktor ekstern meliputi: a) Faktor keluarga terdiri dari cara orang tua mendidik, relasi antar anggota keluarga, suasana rumah, keadaan ekonomi keluarga, pengertian orang tua, dan latar belakang kebudayaan; b) Faktor sekolah terdiri dari metode mengajar, kurikulum, relasi guru dengan siswa, relasi siswa dengan siswa, disiplin sekolah, alat pelajaran, waktu sekolah, standar pelajaran di atas ukuran, keadaan gedung, metode mengajar, dan tugas rumah.

3) Faktor masyarakat terdiri dari: a) kegiatan siswa dalam masyarakat; b) mass media; c) teman bergaul, dan; d) bentuk kehidupan masyarakat.

Berdasarkan teori di atas, nampak bahwa salah satu faktor ekstern yang memepengaruhi belajar peserta didik adalah metode mengajar. Guru sebagai fasilitator pembelajaran memiliki peran penting dalam pemilihan metode mengajar yang efektif untuk meningkatkan hasil belajar peserta didik agar semua peserta didik dapat mengikuti pembelajaran dengan aktif dan merasa senang selama pembelajaran berlangsung. Berdasarkan hasil penelitian terbukti bahwa hasil belajar peserta didik pada kelas yang menggunakan model pembelajaran konvensional masih kurang dibandingkan 
dengan hasil belajar peserta didik yang menggunakan model pembelajaran Project Based Learning (PBL).

Perbedaan Hasil Belajar Siswa yang Menggunakan Model Pembelajaran Project Based Learning (PBL) dibandingkan dengan Hasil Belajar Siswa yang Menggunakan Model Pembelajaran Konvensional melalui Penggunaan Media Unit Kegiatan Belajar Mandiri (UKBM) pada Pengukuran Akhir (Posttest) di Kelas X MIPA SMA Negeri 1 Ciamis

Berdasarkan hasil pengujian pengukuran akhir (posttest) pada mata pelajaran lintas minat Ekonomi di kelas eksperimen (X MIPA 1) dan pada kelas kontrol (X MIPA 2) SMA Negeri 1 Ciamis dengan menggunakan rumus uji $t$-test, diketahui bahwa hasil belajar peserta didik dengan penerapan model pembelajaran project based learning (PBL) lebih efektif dalam meningkatkan hasil belajar siswa dibandingkan dengan penggunaan model pembelajaran konvensional melalui penggunaan media Unit Kegiatan Belajar Mandiri (UKBM). Hal ini dibuktikan dengan nilai thitung sebesar 6,6563 dan nilai $t_{\text {tabel }}$ sebesar 1,6686. Dengan demikian maka $t_{\text {hitung }} \geq t_{\text {tabel }}$ atau 6,6563> 1,6686 ini menunjukan bahwa terdapat perbedaan tingkat hasil belajar peserta didik yang signifikan pada penggunaan model pembelajaran Project Based Learning (PBL) melalui penggunaan media Unit Kegiatan Belajar Mandiri (UKBM) dengan hasil belajar peserta didik yang menggunakan metode konvensional pada pengukuran akhir (posttest).

Perbedaan hasil belajar peserta didik juga dibuktikan dengan adanya presentase peningkatan hasil belajar peserta didik pengukuran akhir (posttest) dengan menggunakan model pembelajaran Project Based Learning (PBL) lebih unggul dibandingkan dengan penggunaan model pembelajaran konvensional karena terdapat perbedaan hasil belajar yang signifikan antara peserta didik pada kelas eskperimen di X MIPA 1 dengan kelas kontrol di X MIPA 2 SMA Negeri 1 Ciamis dengan persentasi peningkatan hasil belajar sebesar $14 \%$.

Dengan model pembelajaran Project Based Learning (PBL) Peserta didik lebih berperan aktif dalam pembelajaran dan ikut serta memberikan solusi nyata terhadap pemecahan permasalahan dengan membuat sebuah proyek, dengan demikian peserta didik akan mengingat pengalaman pembelajaran tersebut dengan baik karenadalam proses pembelajaran Project Based Learning (PBL) peserta didik akan mengkontruksi pembelajaran secara mandiri dan melibatkan pemahaman, kecerdasan, kreativitas, kolaborasi dan tanggung jawab yang dapat meningkatkan hasil belajar peserta didik.

\section{KESIMPULAN}

Berdasarkan hasil penelitian dan pembahasan maka dapat dikemukakan beberapa kesimpulan sebagai berikut:

1. Terdapat perbedaan hasil belajar siswa yang positif dan signifikan dengan kategori N-Gain tinggi pada penggunaan model pembelajaran Project Based Learning(PBL) melalui penggunaan media Unit Kegiatan Belajar Mandiri (UKBM) pada pengukuran awal (pretest) dan pengukuran akhir (posttest) pada kelas eksperimen di kelas X MIPA 1 SMA Negeri 1 Ciamis.

2. Terdapat perbedaan hasil belajar siswa yang yang positif dan signifikan dengan kategori N-Gain sedang pada penggunaan model pembelajaran konvensional melalui penggunaan media Unit Kegiatan Belajar Mandiri (UKBM) pada pengukuran awal (pretest) dan pengukuran akhir (posttest) pada kelas kontrol di kelas X MIPA 2 SMA Negeri 1 Ciamis.

3. Terdapat perbedaan hasil belajar peserta didik yang positif dan signifikan pada penggunaan model pembelajaran Project Based Learning (PBL) lebih unggul dibandingkan dengan hasil belajar peserta didik yang menggunakan metode konvensional pada pengukuran akhir (posttest) melalui penggunaan media Unit Kegiatan Belajar Mandiri (UKBM) di kelas X MIPA SMA Negeri 1 Ciamis. 


\section{REKOMENDASI}

Model pembelajaran Project Based Learning (PBL) melalui penggunaan media Unit Kegiatan Belajar Mandiri (UKBM) dapat digunakan untuk meningkatkan kemampuan siswa pada ranah kognitif lainnya.

\section{UCAPAN TERIMA KASIH}

Penulis mengucapkan terima kasih kepada siswa kelas X MIPA 1 SMA Negeri 1 Ciamis yang telah mendukung terhadap pelaksanaan penelitian ini.

\section{DAFTAR PUSTAKA}

Al-Tabany, T.I.B. 2015. Mendesain Model Pembelajaran Inovatif, Progresif, dan Kontekstual: Konsep, Landasan, dan Implementasinya Pada Kurikulum 2013 (Kurikulum Tematik Integratif/TKI). Jakarta: Kencana.

Arsyad. A., 2016. Media Pembelajaran. Jakarta: Rajawali Pers.

Kemendikbud. 2017. Panduan Pengembangan Unit Kegiatan Belajar Mandiri (UKBM). Jakarta: Ditjen Disdakmen, Direktorat Pembinaan Sekolah Menengah Atas.

Madiastuty, Neka Firda. 2019. Pengaruh Penerapan Model Pembelajaran Project Based Learning (PjBL) melalui Penggunaan Unit Kegiatan Belajar Mandiri (UKBM) Terhadap Hasil Belajar Siswa Pada Materi Koloid di MAN 3 Pekanbaru. Skripsi. Pekanbaru: Fakultas Tarbiyah dan Keguruan Universitas Islam Negeri Sultan Syarif Kasim Riau.

Purwanti, Sri. 2018. Pengaruh Model Pembelajaran Project Based Learning dan Direct Instruction Terhadap Hasil Belajar Ekonomi Siswa Kelas XI IPS di SMA Negeri 6 Kota Jambi. Artikel IImiah. Jambi: Fakultas Keguruan dan Ilmu Pendidikan Universitas Jambi.

Priansa. D. J., 2015. Manajemen Peserta Didik dan Model Pembelajaran: Cerdas, Kreatif, dan Inovatif.Bandung: Alfabeta.

Rusman. 2017. Belajar dan Pembelajaran Berorientasi Standar Proses Pendidikan. Jakarta: Kencana.

Slameto. 2015. Belajar dan Faktor-faktor yang Mempengaruhinya. Jakarta: PT Rineka Cipta.

Sudjana, N. 2017. Penilaian hasil proses belajar mengajar. Bandung: PT. Remaja Rosdakarya.

Sugiyono, 2015. Metode Penelitian Pendidikan (Pendekatan Kuantitatif, Kualitatif, dan R\&D). Bandung: Alfabeta. 
